\title{
Dinuclear UO2(VI), Th(IV), ZrO(IV) and VO(IV) complexes based on some Schiff-base ligands: Synthesis and structural elucidation
}

\author{
${ }^{\mathrm{a}}$ R. K. Mohapatra*, ${ }^{\mathrm{b}} \mathrm{S}$. Ghosh, ${ }^{\mathrm{b}} \mathrm{P}$. Naik and ${ }^{\mathrm{b}}$ D. C. Dash \\ ${ }^{\mathrm{a}}$ Department of Chemistry, Govt. College of Engineering, Keonjhar-758002, Odisha, India, \\ E-mail: ranjank_mohapatra@yahoo.com \\ ${ }^{b}$ School of Chemistry, Sambalpur University, Jyoti Vihar, Burla, Sambalpur-768019, Odisha, India, \\ E-mail: dhruba_dash@yahoo.co.in
}

\begin{abstract}
A series of homo binuclear complexs of the type $\left[\mathrm{M}_{2}\left(\mathrm{~L}^{\prime} \mathrm{L}^{\prime}\right)\left(\mathrm{NO}_{3}\right) \mathrm{n}\left(\mathrm{H}_{2} \mathrm{O}\right)_{2}\right]$, [where $\left.\mathrm{M}=\mathrm{UO}_{2}{ }^{2+}, \mathrm{Th}^{4+}, \mathrm{ZrO}^{2+}\right]$ and $\left[(\mathrm{VO})_{2}\left(\mathrm{~L}^{\prime} \mathrm{L}^{\prime}\right)\left(\mathrm{SO}_{4}\right)\left(\mathrm{H}_{2} \mathrm{O}\right)\right], \mathrm{L}=4$, 17-di (o-hydroxyphenyl)-5,6,9,12,15,16-hexaaza-7,8,13,14-tetraphenyl heptadec-4, 6, 8, 12, 14, 16-hexene or L'= 10:11-benzo-4, 17-di(o-hydroxyphenyl)-5,6,9,12,15,16-hexaaza-7,8,13,14-tetraphenyl heptadec-4, 6, 8, 12, 14, 16-hexene, $\mathrm{n}=2$ for $\mathrm{UO}_{2}{ }^{2+}, \mathrm{ZrO}^{2+} \mathrm{n}=6$ for $\mathrm{Th}^{4+}$, have been synthesized in template method from ethylenediamine/orthophenylene diamine, benzil monohydrazone and salicyldehyde and characterized on the basis of elemental analysis, thermal analysis, molar conductivity, magnetic moment, electronic, infrared, ${ }^{1} \mathrm{H}-\mathrm{NMR}$ studies. The results indicate that the $\mathrm{VO}(\mathrm{IV})$ ion is penta co-ordinated yielding paramagnetic complexes; $\mathrm{UO}_{2}(\mathrm{VI}), \mathrm{ZrO}(\mathrm{IV})$ ions are hexa co-ordinated where as Th(IV) ion is octa co-ordinated yielding diamagnetic complexes of above composition.
\end{abstract}

\section{Keywords}

Schiff Base, Binuclear complexes, Template Synthesis, Structure and Spectral Properties.

\section{Academic Discipline And Sub-Disciplines}

Provide examples of relevant academic disciplines for this journal: Chemistry

\section{SUBJECT CLASSIFICATION}

Chemistry, Coordination chemistry

\section{TYPE (METHOD/APPROACH)}

Provide examples of relevant research types, methods, and approaches for this field: Experimental: synthesis and characterization

\section{Council for Innovative Research}

\author{
Peer Review Research Publishing System
}

Journal: Journal of Advances in Chemistry

Vol 2, No. 1 


\section{INTRODUCTION}

One major topic of interest is to develop homo-multimetallic complexes because they exhibit distinct reactivity pattern as compared to corresponding monometallic complexes ${ }^{1}$. The magnetic interactions and coupling between the metal ions present in such complexes play key role in both natural and synthetic catalysts ${ }^{2}$. As a result, the synthesis and characterization of homo bimetallic complexes continue to attract attention ${ }^{3}$. Following all these observations and as a part of our continuing research on the coordination chemistry of multidentate ligands ${ }^{4-10}$, we report here the synthesis and structural studies of some unknown homo binuclear macrocyclic complexes from the reaction of ethylenediamine/orthophenylene diamine, benzil monohydrazone and salicyldehyde in presence of $\mathrm{UO}_{2}^{2+}, \mathrm{ZrO}^{2+}, \mathrm{Th}^{4+}$ and $\mathrm{VO}^{2+}$ ions.

\section{RESULTS AND DISCUSSION}

The complexes were formulated from the analytical data and molar conductance data support the suggested formulae (Table 1). The complexes are highly coloured and insoluble in water and common organic solvents such as ethanol, methanol, acetone, $\mathrm{CCl}_{4}, \mathrm{CHCl}_{3}$, benzene and ether but moderately soluble in highly coordinating solvents such as DMF and DMSO. They are non-hygroscopic, highly stable under normal conditions and all of them decompose above $250^{\circ} \mathrm{C}$. The molar conductance data in DMSO for the complexes indicate them to be non-electrolyte in nature. However, the conductivity value is higher than as expected for non-electrolytes probably due to partial solvolysis of the complexes in DMSO medium ${ }^{11}$.

Table 1. Analytical and physical data of the complexes

\begin{tabular}{|c|c|c|c|c|c|c|c|c|c|}
\hline \multirow{2}{*}{$\begin{array}{l}\text { SI. } \\
\text { no. }\end{array}$} & \multirow[t]{2}{*}{ Compounds } & \multirow[t]{2}{*}{ Colour } & \multirow{2}{*}{$\begin{array}{l}\text { Yield } \\
\text { (\%) }\end{array}$} & \multirow[t]{2}{*}{$\Lambda_{\mathrm{m}}{ }^{\mathrm{a}}$} & \multicolumn{5}{|c|}{ Found(calc.)\% } \\
\hline & & & & & C & $\mathrm{H}$ & $\mathrm{N}$ & $S$ & M \\
\hline 1 & {$\left[\left(\mathrm{UO}_{2}\right)_{2}(\mathrm{~L})\left(\mathrm{NO}_{3}\right)_{2}\left(\mathrm{H}_{2} \mathrm{O}\right)_{2}\right]$} & $\begin{array}{l}\text { Canary } \\
\text { yellow }\end{array}$ & 67 & 22.12 & $\begin{array}{c}35.06 \\
(35.10)\end{array}$ & $\begin{array}{l}2.62 \\
(2.65)\end{array}$ & $\begin{array}{c}10.27 \\
(10.30)\end{array}$ & - & $\begin{array}{c}31.60 \\
(31.64)\end{array}$ \\
\hline 2 & {$\left[\left(\mathrm{UO}_{2}\right)_{2}\left(\mathrm{~L}^{\prime}\right)\left(\mathrm{NO}_{3}\right)_{2}\left(\mathrm{H}_{2} \mathrm{O}\right)_{2}\right]$} & $\begin{array}{l}\text { Brownish } \\
\text { yellow }\end{array}$ & 69 & 21.25 & $\begin{array}{c}37.03 \\
(37.06)\end{array}$ & $\begin{array}{l}2.65 \\
(2.70)\end{array}$ & $\begin{array}{c}8.96 \\
(9.00)\end{array}$ & - & $\begin{array}{c}30.60 \\
(30.63)\end{array}$ \\
\hline 3 & {$\left[(\mathrm{Th})_{2}(\mathrm{~L})\left(\mathrm{NO}_{3}\right)_{6}\left(\mathrm{H}_{2} \mathrm{O}\right)_{2}\right]$} & $\begin{array}{l}\text { Lemon } \\
\text { yellow }\end{array}$ & 58 & 32.84 & $\begin{array}{c}31.79 \\
(31.84)\end{array}$ & $\begin{array}{c}2.27 \\
(2.29)\end{array}$ & $\begin{array}{r}11.79 \\
(11.82)\end{array}$ & - & $\begin{array}{c}27.93 \\
(27.98)\end{array}$ \\
\hline 4 & {$\left[(\mathrm{Th})_{2}\left(\mathrm{~L}^{\prime}\right)\left(\mathrm{NO}_{3}\right)_{6}\left(\mathrm{H}_{2} \mathrm{O}\right)_{2}\right]$} & Red oxide & 62 & 35.43 & $\begin{array}{c}33.67 \\
(33.72)\end{array}$ & $\begin{array}{l}2.42 \\
(2.45)\end{array}$ & $\begin{array}{r}11.43 \\
(11.47)\end{array}$ & - & $\begin{array}{c}27.12 \\
(27.16)\end{array}$ \\
\hline 5 & {$\left[(\mathrm{ZrO})_{2}(\mathrm{~L})\left(\mathrm{NO}_{3}\right)_{2}\left(\mathrm{H}_{2} \mathrm{O}\right)_{2}\right]$} & Cream & 65 & 31.67 & $\begin{array}{c}44.10 \\
(44.14)\end{array}$ & $\begin{array}{l}3.49 \\
(3.51)\end{array}$ & $\begin{array}{r}11.66 \\
(11.70)\end{array}$ & - & $\begin{array}{c}15.18 \\
(15.21)\end{array}$ \\
\hline 6 & {$\left[(\mathrm{ZrO})_{2}\left(\mathrm{~L}^{\prime}\right)\left(\mathrm{NO}_{3}\right)_{2}\left(\mathrm{H}_{2} \mathrm{O}\right)_{2}\right]$} & $\begin{array}{l}\text { Golden } \\
\text { Brown }\end{array}$ & 64 & 33.85 & $\begin{array}{c}46.18 \\
(46.22)\end{array}$ & $\begin{array}{l}3.50 \\
(3.53)\end{array}$ & $\begin{array}{r}11.19 \\
(11.23)\end{array}$ & - & $\begin{array}{c}14.57 \\
(14.60)\end{array}$ \\
\hline 7 & {$\left[(\mathrm{VO})_{2}(\mathrm{~L})\left(\mathrm{SO}_{4}\right)\left(\mathrm{H}_{2} \mathrm{O}\right)\right]$} & black & 63 & 16.35 & $\begin{array}{c}50.62 \\
(50.67)\end{array}$ & $\begin{array}{l}3.79 \\
(3.83)\end{array}$ & $\begin{array}{c}8.02 \\
(8.06)\end{array}$ & $\begin{array}{l}6.10 \\
(6.14)\end{array}$ & $\begin{array}{c}9.73 \\
(9.78)\end{array}$ \\
\hline 8 & {$\left[(\mathrm{VO})_{2}\left(\mathrm{~L}^{\prime}\right)\left(\mathrm{SO}_{4}\right)\left(\mathrm{H}_{2} \mathrm{O}\right)\right]$} & brown & 65 & 18.58 & $\begin{array}{c}52.71 \\
(52.74)\end{array}$ & $\begin{array}{l}3.81 \\
(3.84)\end{array}$ & $\begin{array}{c}7.65 \\
(7.69)\end{array}$ & $\begin{array}{c}5.83 \\
(5.86)\end{array}$ & $\begin{array}{c}9.30 \\
(9.34)\end{array}$ \\
\hline
\end{tabular}

\section{IR spectra}

As the Schiff base ligands could not be isolated, the spectra of the complexes were compared with spectra of the starting materials and other related compounds. The IR spectra of the complexes show strong bands appearing at 1615 and $\sim 1060 \mathrm{~cm}^{-1}$ assignable to azomethine $\mathrm{vC}=\mathrm{N}$ and $\mathrm{vN}-\mathrm{N}$. The position of former band at comparatively lower frequency region than usual free $\mathrm{vC}=\mathrm{N}$ value ${ }^{12}$ and that of later band at comparatively higher frequency region than that of free $\mathrm{N}-\mathrm{N}^{13}$ leads us to suggest that azomethine nitrogen atom has taken part in complexation as evidenced from the appearance of band in the region $\sim 470 \mathrm{~cm}^{-1}$ due to $\mathrm{v}(\mathrm{M}-\mathrm{N})^{14}$. The occurrence of N-N band at higher frequency in the IR spectra of the complex is due to reduction of the repulsion between the lone pair of nitrogen atoms as a result of coordination via azomethine nitrogen atoms. A sharp band due to the phenolic $(\mathrm{O}-\mathrm{H})$ of salicylaldehyde is absent in the complexes indicating the coordination of the phenolic oxygen after deprotonation to the metal ion, which is further supported by the appearance of a band due to $\vee \mathrm{C}-\mathrm{O}$ (phenolic) at much higher frequencies $\left(\sim 1450 \mathrm{~cm}^{-1}\right)$ in the complexes due to partial double bond character. The coordination of phenolic oxygen is further supported by the appearance of a non ligand band at $520-540 \mathrm{~cm}^{-1}$ due to $v \mathrm{M}-\mathrm{O}^{15}$. 
The uranyl complexes exhibit a strong band at $\sim 935-920 \mathrm{~cm}^{-1}$ and the medium intensity band at $\sim 840-825 \mathrm{~cm}^{-1}$ assignable to $v_{a s}(\mathrm{O}=\mathrm{U}=\mathrm{O})$ and $\mathrm{v}_{\mathrm{s}}(\mathrm{O}=\mathrm{U}=\mathrm{O})$ mode respectively ${ }^{16}$. The co-ordination of nitrate ions in unidentate manner has been indicated by the appearance of additional band at the region $\sim 1480 \mathrm{~cm}^{-1}$ and $\sim 1380 \mathrm{~cm}^{-1}$ corresponding to the $\mathrm{V}_{4}$ and $v_{1}$ modes of the vibration respectively, of coordinating nitrate ion under $C_{2 v}$ symmetry ${ }^{17}$. The magnitude of $\Delta v=\left(v_{4}-v_{1}\right)=$ $100 \mathrm{~cm}^{-1}$ shows the unidentate coordination of the nitrate ion. The zirconyl complexes exhibit one strong band in the region $\sim 950 \mathrm{~cm}^{-1}$ which can be attributed to the $\mathrm{v}(\mathrm{Zr}=\mathrm{O})$ as reported earlier indicating the presence of $(\mathrm{Zr}=\mathrm{O})^{2+}$ moiety in these complexes. In the oxovanadium polychelates strong bands at $\sim 955 \mathrm{~cm}^{-1}$ are assigned to $v(V=O)$ modes. However, these bands are absent in the complexes of Th(IV). However in vanadyl complexes, an additional series of four bands appeared at $\sim 1160, \sim 1125, \sim 860 \& \sim 635 \mathrm{~cm}^{-1}$ indicating the coordination of sulphate group in unidentate manner through oxygen atom ${ }^{18}$; the symmetry being lowered from $T_{D}$ to $C_{3 v}$ upon coordination. Besides the bands observed at $\sim 3460 \mathrm{~cm}^{-1}$ may be assigned to $\mathrm{v}(\mathrm{O}-\mathrm{H})$ of coordinated or lattice water.

\section{Thermal analysis}

All these complexes follow the same pattern of thermal decomposition. The complexes remain almost unaffected upto $\sim 140^{\circ} \mathrm{C}$. After this a slight depression upto $200^{\circ} \mathrm{C}$ is observed. The weight loss at this temperature range is equivalent to one water molecule for the complexes (7) and (8), two water molecules for other complexes indicating them to be coordinated water in conformity with our earlier observations from analytical and IR spectral investigations. Simultaneous elimination of coordinated water suggests them to be in the same chemical environment ${ }^{19}$. The anhydrous complexes remain stable upto $\sim 355^{\circ} \mathrm{C}$ then the complexes show rapid degradation presumably due to decomposition of organic constituents of the complex molecules as indicated by the steep fall in the percentage weight loss. The decomposition continues upto $\sim 700^{\circ} \mathrm{C}$ and reaches to a stable product in each complex as indicated by the consistency in weight in the plateau of the thermogram. The decomposition temperature varies for different complexes as shown in Table 2 . The representative thermogram of $\left[(\mathrm{ZrO})_{2}(\mathrm{~L})\left(\mathrm{NO}_{3}\right)_{2}\left(\mathrm{H}_{2} \mathrm{O}\right)_{2}\right]$ complex is shown in Fig. 1. The thermal stability of the complexes decreases in the order:

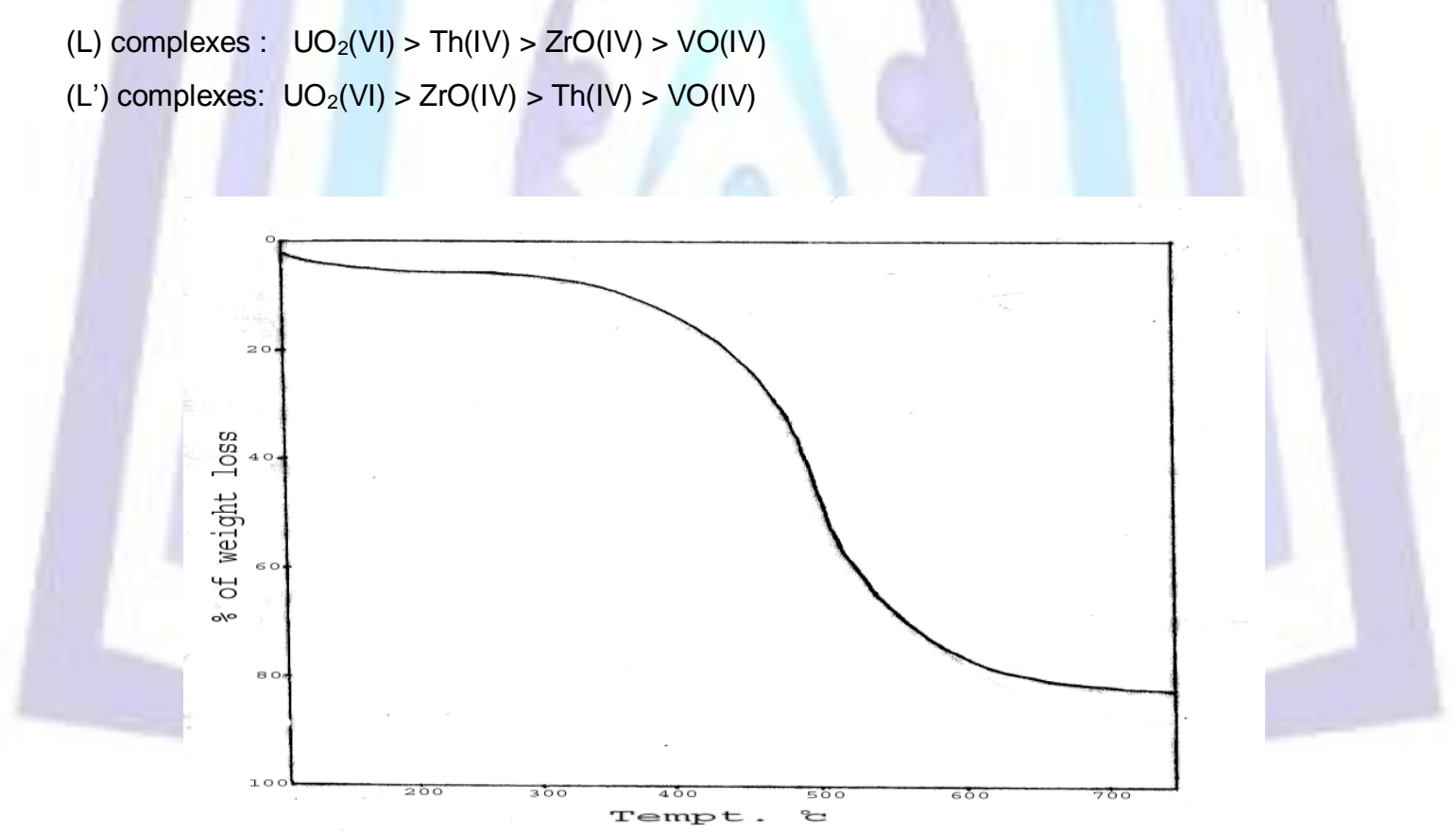

Fig. 1. Thermogram of $\left[(\mathrm{ZrO})_{2}(\mathrm{~L})\left(\mathrm{NO}_{3}\right)_{2}\left(\mathrm{H}_{2} \mathrm{O}\right)_{2}\right]$ 
Table 2. Important features of thermo gravimetric analysis (TGA)

\begin{tabular}{|c|c|c|c|c|c|c|}
\hline $\begin{array}{l}\text { SI. } \\
\text { no. }\end{array}$ & $\begin{array}{l}\text { Total wt. for } \\
\text { TG(mg) }\end{array}$ & $\begin{array}{c}\text { Temp. range of } \\
\text { water loss } \\
(0 \mathrm{C})\end{array}$ & $\begin{array}{c}\% \text { of water } \\
\text { loss } \\
\text { Found } \\
\text { (calcd.) }\end{array}$ & $\begin{array}{c}\text { Decomposition } \\
\text { temperature }\left({ }^{0} \mathrm{C}\right)\end{array}$ & $\begin{array}{l}\text { \% weight of } \\
\text { residue } \\
\text { Found } \\
\text { (calcd.) }\end{array}$ & $\begin{array}{l}\text { Composition of } \\
\text { the residue }\end{array}$ \\
\hline 1 & 108 & $140-185$ & $\begin{array}{c}3.61 \\
(3.64)\end{array}$ & $385-715$ & $\begin{array}{c}36.84 \\
(36.87)\end{array}$ & $\mathrm{U}_{3} \mathrm{O}_{8}$ \\
\hline 2 & 105 & $140-190$ & $\begin{array}{c}3.50 \\
(3.52)\end{array}$ & $380-690$ & $\begin{array}{c}35.65 \\
(35.69)\end{array}$ & $\mathrm{U}_{3} \mathrm{O}_{8}$ \\
\hline 3 & 102 & $135-200$ & $\begin{array}{l}3.45 \\
(3.49)\end{array}$ & $365-680$ & $\begin{array}{c}31.81 \\
(31.84)\end{array}$ & $\mathrm{ThO}_{2}$ \\
\hline 4 & 97 & 140-195 & $\begin{array}{r}1.32 \\
(3.37)\end{array}$ & $360-680$ & $\begin{array}{c}30.86 \\
(30.91)\end{array}$ & $\mathrm{ThO}_{2}$ \\
\hline 5 & 98 & $130-185$ & $\begin{array}{l}3.14 \\
(3.16)\end{array}$ & $355-675$ & $\begin{array}{c}20.52 \\
(20.56)\end{array}$ & $\mathrm{ZrO}_{2}$ \\
\hline 6 & 101 & $135-180$ & $\begin{array}{l}3.00 \\
(3.03)\end{array}$ & $370-690$ & $\begin{array}{c}19.70 \\
(19.74)\end{array}$ & $\mathrm{ZrO}_{2}$ \\
\hline 7 & 84 & $135-185$ & $\begin{array}{c}3.61 \\
(3.65)\end{array}$ & $360-670$ & $\begin{array}{c}17.41 \\
(17.46)\end{array}$ & $\mathrm{V}_{2} \mathrm{O}_{5}$ \\
\hline 8 & 86 & $130-180$ & $\begin{array}{c}3.40 \\
(3.43)\end{array}$ & $350-665$ & $\begin{array}{c}16.62 \\
(16.66)\end{array}$ & $\mathrm{V}_{2} \mathrm{O}_{5}$ \\
\hline
\end{tabular}

\section{Electronic spectra}

The electronic spectra of the $\mathrm{UO}_{2}(\mathrm{VI})$ complexes are quite similar. The complexes display mainly one weak band at $\sim 455$ $\mathrm{nm}$ and a highly intense band at $\sim 275-290 \mathrm{~nm}$, which may be due to ${ }^{1} \Sigma_{g}{ }^{+} \rightarrow{ }^{3} \Pi_{\mathrm{u}}$ transitions and charge transfer transitions respectively ${ }^{20}$. It may be noted that the band occurring at $365 \mathrm{~nm}$ is due to uranyl moiety because of apical oxygen $\rightarrow f^{0}(U)$ transition is being merged with the ligand band due to $n \rightarrow \Pi^{*}$ transition as evident from broadness and intensity. The electronic spectra of $\mathrm{Th}(\mathrm{IV})$ and $\mathrm{ZrO}(\mathrm{IV})$ exhibit only one extra highly intensive band in the region 350-375 nm which may be due to charge transfer band besides the ligand bands. However the electronic spectra could not provide structural details of these complexes. The electronic spectra of VO(IV) complexes show three bands at $\sim 12430, \sim 18470$ and $\sim 25880$ $\mathrm{cm}^{-1}$ corresponds to transitions, $d_{x y}\left(b_{2}\right) \rightarrow d_{x z} d_{y z}(e), d_{x y}\left(b_{2}\right) \rightarrow d_{x-y}^{2}{ }^{2}\left(b_{1}\right)$ and $d_{x y}\left(b_{2}\right) \rightarrow d_{z}{ }^{2}\left(a_{1}\right)$ respectively, indicating the complexes to be in distorted octahedral environment under $\mathrm{C}_{4 \mathrm{v}}$ symmetry ${ }^{21}$.

\section{${ }^{1} \mathrm{H}$ NMR spectra}

The ${ }^{1} \mathrm{H}$ NMR spectra of the diamagnetic complexes are recorded in DMSO- $\mathrm{d}_{6}$ medium. The complexes do not show any signal attributable to amino protons, suggesting that the proposed skeleton has been formed by the condensation reactions, which is also conformed from the IR spectra of the complexes. The disappearance of the signal due to the phenolic $\mathrm{OH}$ protons (which is normally observed at $\delta \sim 13.07 \mathrm{ppm}$ ) and the downfield signal $(\delta \sim 8.32 \mathrm{ppm})$ due to the azomethine protons as compared to free $-\mathrm{CH}=\mathrm{N}(\delta \sim 8.55 \mathrm{ppm})$ in the corresponding complexes, indicate the coordination of the phenolic oxygen (through deprotonation) and azomethine nitrogen to the metal ion ${ }^{22}$. The same result was confirmed by the IR spectra. On the other hand the complexes show a complex broad multiplet in the region $\delta 6.53$ $8.06 \mathrm{ppm}$ corresponding to eight aromatic protons of two oxophenyl groups and twenty aromatic protons of $\mathrm{C}_{6} \mathrm{H}_{5}-\mathrm{C}=\mathrm{N}$ groups. For all the complexes, the signals due to $(-\mathrm{NH}-\mathrm{N}=; 2 \mathrm{H})$ protons appear at $\delta 5.98-6.12 \mathrm{ppm}$. In the complexes (1), (3), (5) and (7) a signal is observed at $\delta 3.75 \mathrm{ppm}$ due to 4 protons $\left(\mathrm{NCH}_{2} \mathrm{CH}_{2} \mathrm{~N}\right)^{23}$. Besides, an additional peak at $\delta \sim 3.5$ $\mathrm{ppm}$ is observed in all the complexes indicating the presence of coordinated water ${ }^{24}$. complexes.

Based on the foregoing observations the following tentative structures have been proposed for the present 


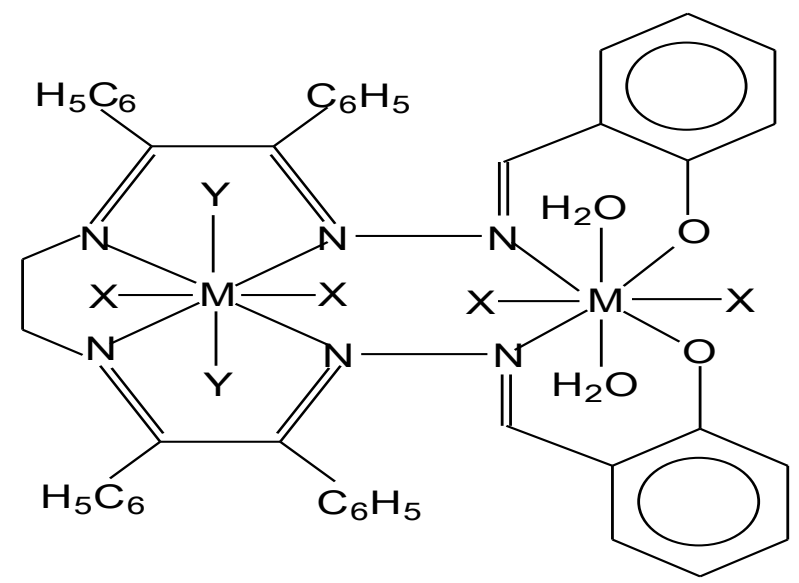

Fig. 2. Complexes with $L$ ligand

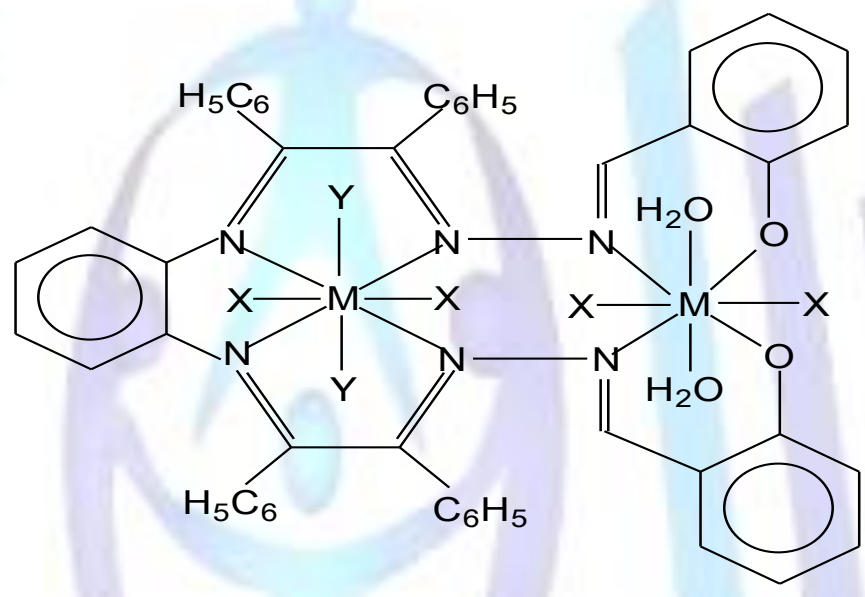

Fig. 3. Complexes with L' ligand

$\mathrm{M}=\mathrm{UO}_{2}(\mathrm{VI}), \mathrm{ZrO}(\mathrm{IV})$ and $\mathrm{Th}(\mathrm{IV})$

$\mathrm{Y}=\mathrm{NO}_{3}{ }^{-}$for $\mathrm{Th}(\mathrm{IV})$

$\mathrm{Y}=0$ for $\mathrm{UO}_{2}(\mathrm{VI})$ and $\mathrm{ZrO}(\mathrm{IV})$

$\mathrm{X}=\mathrm{NO}_{3}$

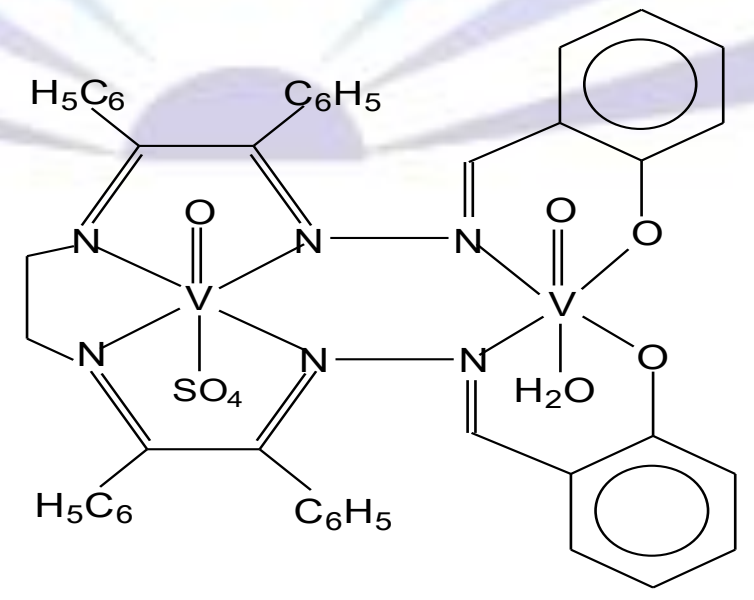

Fig. 4. $\left[(\mathrm{VO})_{2}(\mathrm{~L})\left(\mathrm{SO}_{4}\right)\left(\mathrm{H}_{2} \mathrm{O}\right)\right]$ 


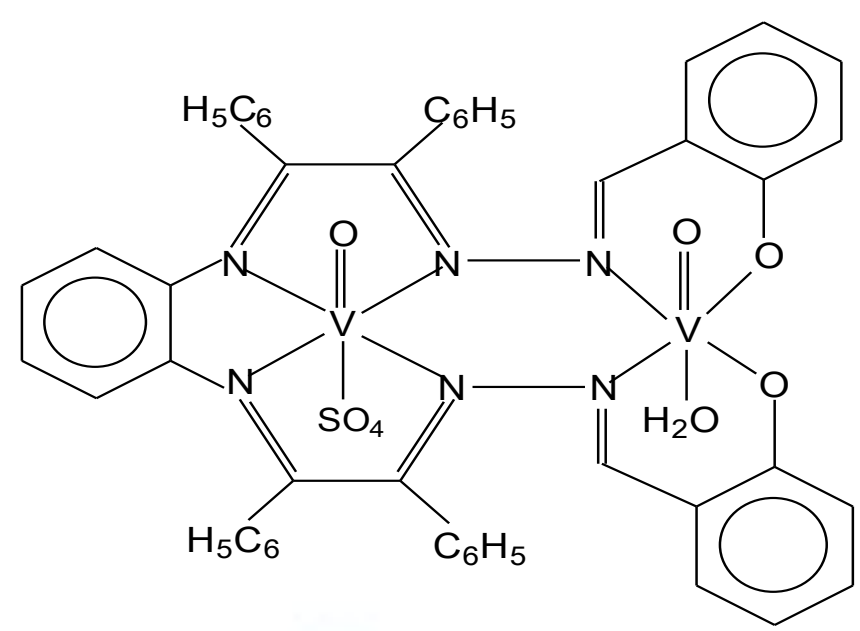

Fig. 5. $\left[(\mathrm{VO})_{2}\left(\mathrm{~L}^{\prime}\right)\left(\mathrm{SO}_{4}\right)\left(\mathrm{H}_{2} \mathrm{O}\right)\right]$

\section{Materials and methods}

All the chemicals used of AR grade. The solvents were purified before use by standard procedures.

\section{Preparation of benzilmonohydrazone}

The analytical monohydrazones were synthesized according to literature method ${ }^{25}$. As the isolation of Schiff base ligand proved futile, all the metal complexes were synthesized (in an identical method) in situ by taking different amount of metal salts, ethylene diamine/orthophenylene diamine, benzilmonohydrazone and salicyldehyde.

\section{Preparation of the complexes of the type $\left[\mathrm{M}_{2}(\mathrm{~L})\left(\mathrm{NO}_{3}\right)_{\mathrm{n}}\left(\mathrm{H}_{2} \mathrm{O}\right)_{2}\right], \mathrm{M}=\mathrm{UO}_{2}{ }^{2+}, \mathrm{ZrO}^{2+}, \mathrm{Th}^{4+}$ and $\left[(\mathrm{VO})_{2}(\mathrm{~L})\left(\mathrm{SO}_{4}\right)\left(\mathrm{H}_{2} \mathrm{O}\right)\right]$}

An ethanolic solution of hydrated $\mathrm{UO}_{2}(\mathrm{VI}) / \mathrm{Th}(\mathrm{IV}) / \mathrm{ZrO}(\mathrm{IV})$ nitrates /vanadyl sulphate $(1 \mathrm{mmol}$ in $10 \mathrm{~mL})$ was added to a hot ethanolic solution of the mixture of ethylene diamine $(1 \mathrm{mmol}$ in $10 \mathrm{~mL})$ and benzil monohydrazone $(2 \mathrm{mmol}$ in $20 \mathrm{~mL})$. The resulting mixture was refluxed on a water bath for 2-3 hours during which a coloured complex was precipitated out in each case. The ethanolic suspension of the complexes was treated with salicyldehyde ( $2 \mathrm{mmol}$ in $20 \mathrm{~mL})$, which is followed by the corresponding metal salts $(1 \mathrm{mmol}$ in $10 \mathrm{~mL}$ EtOH). The mixture was again refluxed for 3-4 hours on a water bath during which the metal complexes of different colour than the precursor complexes were obtained (Table-1). The progress of the reaction was signaled by colour change of the resulting solution. These were filtered off, washed several times with ethanol followed by ether and finally dried in vacuo over anhydrous $\mathrm{CaCl}_{2}$ (fused)

\section{Preparation of the complexes of the type $\left[\mathrm{M}_{2}\left(\mathrm{~L}^{\prime}\right)\left(\mathrm{NO}_{3}\right)_{\mathrm{n}}\left(\mathrm{H}_{2} \mathrm{O}\right)_{2}\right], \mathrm{M}=\mathrm{UO}_{2}{ }^{2+}, \mathrm{ZrO}^{2+}, \mathrm{Th}^{4+}$ and $\left[\left(\mathrm{VO}_{2}\left(\mathrm{~L}^{\prime}\right)\left(\mathrm{SO}_{4}\right)\left(\mathrm{H}_{2} \mathrm{O}\right)\right]\right.$}

Same procedure was adopted for preparation of $\left[\mathrm{M}_{2}\left(\mathrm{~L}^{\prime}\right)\left(\mathrm{NO}_{3}\right)_{n}\left(\mathrm{H}_{2} \mathrm{O}\right)_{2}\right]$ and $\left[(\mathrm{VO})_{2}\left(\mathrm{~L}^{\prime}\right)\left(\mathrm{SO}_{4}\right)\left(\mathrm{H}_{2} \mathrm{O}\right)\right]$ by taking orthophenylene diamine instead of ethylene diamine.

\section{Analysis and Physical Measurements}

The metal contents in the complexes were determined gravimetrically following standard procedures ${ }^{26}$. Sulphur was determined as $\mathrm{BaSO}_{4}$. Room temperature magnetic susceptibilities were measured by Gouy method using $\mathrm{Hg}\left[\mathrm{Co}(\mathrm{NCS})_{4}\right]$ as the calibrant. The molar conductance measurements were carried out at room temperature with a Toshniwal conductivity Bridge (Model CL-01-06, cell constant $0.5 \mathrm{~cm}^{-1}$ ) using $1 \times 10^{-3} \mathrm{M}$ solution of the complexes in DMSO. Carbon, hydrogen and nitrogen contents of the complexes were determined by using a MLW-CHN microanalyser. FTIR spectra in $\mathrm{KBr}$ pellets were recorded on a Varian FTIR spectrophotometer, Australia. The electronic spectra of the complexes in DMSO were recorded on a Perkin Elmer spectrophotometer. Thermogravimetric analysis was done by Netzch-429 thermoanalyser. The ${ }^{1} \mathrm{H}-\mathrm{NMR}$ spectra of the complexes were recorded in DMSO- $\mathrm{d}_{6}$ medium on Jeol GSX-400 model equipment.

\section{Acknowledgement}

The authors gratefully acknowledge the services rendered by Director, Regional Sophisticated Instrumentation Center, I.I.T., Madras, for recording the spectra.

\section{References}

1. J. B. Carlsor, G. Davies and P. Vorous, Inorg. Chem., 1994, 33, 2334.

2. A. K. Ladavos, F. Kooli, S. Moreno, S. P. Skaribas, P. J Pomonis, W. Jones and G. Poncelet, Appl. Clay Sci., 1998, 13, 49.

3. S. K. Dutta, K. K. Nanda, U. Florke, M. Bhadbhade and K. Nag, J. Chem. Soc. Dalton Trans., 1996, 2371.

4. D. C. Dash, R. K. Mohapatra, S. Ghosh and P. Naik, J. Korean Chem. Soc., 2008, 52(5), 468. 
5. D. C. Dash, R. K. Mohapatra, S. Ghosh and P. Naik, J. Indian Chem. Soc., 2009, 86, 121.

6. R. K. Mohapatra, J. Indian Chem. Soc., 2010, 87, 1251.

7. R. K. Mohapatra and D. C. Dash, J. Korean Chem. Soc., 2010, 54(4), 395.

8. D. C. Dash, A. Mahapatra, P. Naik, R. K. Mohapatra and S. K. Naik, J. Korean Chem. Soc., 2011, 55(3), 412.

9. R. K. Mohapatra, S. Ghosh, M. Dash, A. Mahapatra and D. C. Dash, Che. Sci. Rev. Lett., 2012, 1(2), 96.

10. R. K. Mohapatra, S. Ghosh, M. Dash, A. Mahapatra and D. C. Dash, J. Korean Chem. Soc., 2012, 56(1), 62.

11. K. C. Dash, P. S.Mansingh, R. R. Mohanty and S. Jena, Indian J. Chem., 1996, 35A, 480.

12. R. C. Maurya, P. Patel and S. Rajput, Synth. React. Inorg. Met.-Org. Chem., 2003, 33, 817.

13. C. N. R. Rao, "Chemical Application of IR Spectroscopy", Academic Press, New York and London, 1963.

14. J. R. Ferraro, "Low Frequency Vibrations of Inorganic and Coordination Compounds", Plenum Press, New York, 1971.

15. H. R.Singh and B. V. Agarwala, J. Indian Chem. Soc., 1988, 35, 591.

16. J. Selbin, Angew. Chem., 1996, 5, 712.

17. R. P. Singh and J. P. Tandon, Indian J. Chem., 1980, 19A, 602.

18. D. S. Rani, P. V. Ananthalakshmi and V. Jayatyagaraju, Indian J. Chem., 1999, 38A, 843.

19. B. Singh, P. L. Murya, B. R. Agrawal and A. K. Dey, J. Indian Chem. Soc., 1982, 59, 29.

20. K. B. Gudasi and T. R. Goudar, J. Indian Chem. Soc., 2002, 79, 529.

21. M. C. Saha, R. Roy, M. K. Ghosh and P. S. Roy, Indian J. Chem., 1987, 26A, 48.

22. J. Liu, B. Zhang, B. Wu, K. Zhang and S. Hu, Turk J. Chem., 2007, 31, 623.

23. T. A. Khan, S. S. Hasan, N. Jahan, A. K. Mohamed and K. S. Islam, Indian J. Chem., 2000, 39A, 1090.

24. S. J. Swamy and K. Bhaskar, Indian J. Chem., 1999, 84A, 963.

25. R. H. Holm, G. W. Everestt (J) and A. Chakrabarty, "Progress in Inorganic Chemistry”, Interscience, $1966,7,83$.

26. A. I. Vogel, “A Hand Book of Quantitative Inorganic Analysis”, 2nd ed., Longman, ELBS, London, 1966.

\section{Author' biography with Photo}

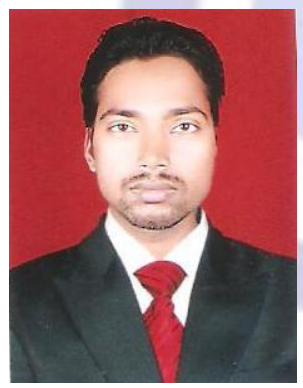

Dr. R. K. Mohapatra, M.Sc., M.Phil.,Ph.D. (Sambalpur University) has been working as a lecturer in chemistry at Govt. College of Engineering, Keonjhar, Odisha, India. He has 20 national and international publications to his credit. $\mathrm{He}$ has presented various research works in nearly 10 national and international conferences. His focus of research interest is Coordination Chemistry, particularly synthesis and characterization of metal complexes. With a consistently brilliant academic records, the author has a rich experience over the years in teaching. 